\title{
STUDENTS' ENGLISH LESSON ATTITUDES AND ITS EFFECTS ON THEIR ENGLISH ACHIEVEMENT
}

\author{
Yuditha Putri Wiwaharini \\ Widya Mandala Catholic University Surabaya \\ yudithaaputri@yahoo.com
}

\begin{abstract}
This research is aimed to analyze students' English lesson attitude and its effect on their English achievement. This research is a preexperimental and it was carried out at one joint-cooperation school in Surabaya, Indonesia. Since English is the language that mostly used at the joint-cooperation school, the parents that sent their children there must have high expectations of their children's English ability. This pressure can affect the students in learning English in the class. Some students will have negative attitudes in learning English because their parents do not want them to fail. Therefore, the researcher took a sample of 17 students in grade 3 as her subjects. The writer used a questionnaire to measure students' attitude towards English lesson and compare it with students' English score. The result shows that students' attitudes do affect their English achievement. Those students who have positive attitudes towards English will stimulate their mood to absorb the information better.
\end{abstract}

Keywords: language attitude, motivation, English achievement

\section{INTRODUCTION}

Most of Indonesian society nowadays agree to the statement that the English language is needed in many working or networking areas. Indonesian parents are starting to expect their children to start learning English at an earlier age. That is why many parents prefer to send their children to a bilingual school. They are hoping that their children will be well-prepared for their future career. Many parents also force their children to enroll to school at a very young age, ask their children to join English private course, provide them with many English books to read and feed their children with English language cartoons. All of these supports are only to make sure their children won't consider as slow learner when they are entering their real life, Sukarta, Y. (2017).

Young learners are never easy to teach. Some of them are just about playing and mumbling. Teachers are expected to be more creative to teach these young students to make them attracted to the lesson. However, teaching a new language to children is different compared to adults. Many researchers believed that new languages should be taught to an individual at their critical age. The age of below 9 is believed to be the critical age for children to learn new languages so that they can sound and perform like the native as it is also supported by (Moskovsky, 2001). According to Granena, G. (2018) There are consecutive sensitive periods for each of the language domains, in the following order: phonology (between age 
0 and age 6) lexis and collocation (between age 0 and age 10) morpho-syntax (between age 0 and age 12).

In Indonesia, only private or joint cooperation school that make English as their prior subject since kindergarten level. Public schools and other kinds of schools did not include English in their curriculum. Expectations toward students' English achievement tend to be very high. Most parents expect their children to master the language as soon as possible. Therefore, many students in English class might not enjoy the lesson because of their English lesson attitude. The students are afraid of making a mistake and getting a bad score in the English lesson. Some of their parents also expect them to achieve an outstanding score.

According to Crystal (2003) language attitudes are the people's way of feeling and receiving their language or other people's language (p. 215). Furthermore, Myers-Scotton (2006) defines language attitudes as "subjective evaluations" of a language (p. 120). It is believed that the feelings or attitude of oneself may affect their learning and even their achievement. If the students did not enjoy the lesson, most likely they will not pay attention and will perform poorly in the class. Hancock (1972) states, "attitude is learned behavior, and, consequently, can be changed from negative to positive by activities and experiences which are perceived to be meaningful by the learner" (p. 146). Unfortunately, not every teacher or school can provide good and meaningful learning to the students. As a result, some students in the English class might have negative attitude towards the lesson and it can affect their learning and achievement process. This paper is discussing whether any relationship between students' English lesson attitude and their English achievement.

\section{THEORITICAL FRAMEWORK}

The theoretical framework used in this study is proposed by Gardner (1980). There are many factors on how learners result their English achievement. One of the most important factors is their attitude towards the language they are learning, in this case, English. Gardner (1980), defines the term attitude as an inference which is made on the basis of a complex of beliefs about the attitude object. On the other hand, Gardner (1985) considers attitudes as components of motivation in language learning. Motivation refers to the combination of effort plus desire to achieve the goal of learning the language plus favorable attitudes toward learning the language. Based on the above classification, the writer also attempts to investigate correlation between learners' English lesson attitude and their English achievement.

\section{METHOD}

The writer took the sample of her research by using purposive sampling. The subjects used were 17 elementary students in joint cooperation school or SPK (sekolah pendidikan kerjasama). Joint cooperation school is used to be called international school, until the year of 2017. It has to change the name because the government wanted to unite all the education institution throughout the country so that we have the same standard and vision to achieve. In joint cooperation school, English language is used to be the medium language to interact with people inside, including teachers, peers and staff. The subjects of this research were widely 
exposed to English language in many forms such as books, songs, movies and other source. They are expected to use their English all the time.

The writer collected two types of data in this research. The first one is students' attitude towards English lesson. This data obtained from a questionnaire distributed to them. Before distributing the questionnaire to the subject, the researcher asked some students from the other class to be the pilot group to test the communicative of the questionnaire. The second data is the students' English achievement. The writer took the students' English achievement based on their daily score since the writer is the teacher herself. The questionnaire is adapted from Foreign Language Classroom Anxiety Scale (FLCAS) questionnaire designed by Horwitz (1986). The writer changed most of the part so that it will fit the students' language and thinking level. The questionnaire is shown as followed:

Table 1: The questionnaire form

\begin{tabular}{|c|c|c|}
\hline I like to learn English & Yes $\odot$ & No $\because$ \\
\hline Learning English is important for my future & Yes $\Theta$ & No $\cong$ \\
\hline English is a hard lesson & Yes $\Theta$ & No $(\because)$ \\
\hline Speaking English made me feel scared & Yes $\odot$ & No $\stackrel{\because}{\varrho}$ \\
\hline I'm afraid of making mistake in speaking English & Yes $\odot$ & No $\Leftrightarrow$ \\
\hline I can talk English fluently with my friends & Yes $\odot$ & No $(\vdots)$ \\
\hline I can read English book individually & Yes $\odot$ & No $\Theta$ \\
\hline I always use English to talk to everyone & Yes $\odot$ & No $\cong$ \\
\hline
\end{tabular}

Why do I love / hate to learn English:

\section{FINDINGS}

Table 2 has shown the result of the questionnaire given by the writer, each number on the questionnaire has its purpose to measure students' anxiety and attitudes. Their answer towards the questions can be later determined as a positive attitude or negative attitude towards English. The more students answer the question in a negative way, the more negative result will appear. Since the subjects of this study were elementary students, the writer made the questionnaire simpler than it usually does. During the questionnaire session, the students may ask questions to the writer about some vocabularies they confused about. 
Table 2: The results of questionnaire of students' anxiety and attitude

\begin{tabular}{|l|l|l|l|l|l|l|l|l|l|}
\hline No. & Name & Q1 & Q2 & $\mathbf{Q 3}$ & $\mathbf{Q 4}$ & $\mathbf{Q 5}$ & $\mathbf{Q 6}$ & $\mathbf{Q 7}$ & Q8 \\
\hline 1. & Carol & YES & YES & NO & NO & YES & YES & YES & NO \\
\hline 2. & Christian & YES & YES & NO & NO & NO & NO & YES & YES \\
\hline 3. & Clara & YES & YES & NO & NO & YES & YES & YES & YES \\
\hline 4. & Devin & YES & YES & NO & NO & YES & NO & NO & YES \\
\hline 5. & Sharren & YES & YES & NO & NO & YES & NO & YES & NO \\
\hline 6. & Edgar & YES & YES & NO & NO & NO & NO & NO & NO \\
\hline 7. & Eugene & YES & YES & NO & NO & NO & NO & YES & YES \\
\hline 8. & Jazreel & YES & YES & NO & NO & NO & YES & YES & NO \\
\hline 9. & Fero & YES & YES & NO & NO & YES & NO & YES & NO \\
\hline 10. & Gracelyn & YES & YES & NO & NO & NO & NO & YES & YES \\
\hline 11. & Helen & YES & YES & NO & NO & NO & YES & YES & YES \\
\hline 12. & Joline & YES & YES & NO & NO & NO & YES & YES & YES \\
\hline 13. & Josua & YES & YES & NO & NO & NO & NO & YES & NO \\
\hline 14. & Kenichi & YES & YES & NO & NO & NO & NO & YES & NO \\
\hline 15. & Leon & YES & YES & YES & YES & YES & YES & YES & NO \\
\hline 16. & Calvin & YES & YES & NO & NO & NO & YES & YES & NO \\
\hline 17. & Sebastian & YES & YES & NO & NO & NO & YES & YES & NO \\
\hline
\end{tabular}

In table 3 below, the students' answers due to the questionnaire were elaborated and explained. After the writer gets all the questionnaires back, she then counted the students' attitude towards English lesson. Most of the students showed a positive attitude towards English lesson. Many of them said that learning English in their class was fun and enjoyable.

Table 3: Students' positive attitude

\begin{tabular}{|c|c|c|c|}
\hline Name & Positive attitude & $\begin{array}{c}\text { Negative } \\
\text { attitude }\end{array}$ & Result \\
\hline Carol & 6 & 2 & Positive attitude \\
\hline Christian & 7 & 1 & Positive attitude \\
\hline Clara & 8 & - & Positive attitude \\
\hline Devin & 5 & 3 & Positive attitude \\
\hline Sharren & 5 & 3 & Positive attitude \\
\hline Edgar & 5 & 3 & Positive attitude \\
\hline Eugene & 7 & 1 & Positive attitude \\
\hline Jazreel & 7 & 1 & Positive attitude \\
\hline Fero & 5 & 3 & Positive attitude \\
\hline Gracelyn & 7 & 1 & Positive attitude \\
\hline Helen & 8 & - & Positive attitude \\
\hline Joline & 8 & - & Positive attitude \\
\hline Josua & 6 & 2 & Positive attitude \\
\hline Kenichi & 6 & 2 & Positive attitude \\
\hline Leon & 4 & 4 & Neutral attitude \\
\hline Calvin & 7 & 1 & Positive attitude \\
\hline Sebastian & 7 & 1 & Positive attitude \\
\hline
\end{tabular}


Positive attitudes towards English questions were put on number 1, 2, 6, 7, 8 when they answer yes. In the learning process, the students need to show a positive attitude towards the lesson. They will need to get involved in the class as well as being active in the class. The students also give respond due to the essay questions and most of them have a positive attitude as follow:

I like to learn English because the teacher is nice - Christian

I love English because it's fun and sometimes miss make joke-Devin

I love to learn English because it's easy and/or fun - Edgar, Eugene, Fero, Gracelyn, Helen, Sebastian

After discussing the result of table 3, most of the students showed a positive attitude in the English lesson. Only one student called Leon had a neutral result. 4 positive attitudes and 4 negative attitudes. Comparing to the score shown in table 4 below, Leon's score tends to be the lowest score among the class even though Leon passed the standard score which is 75 . Leon is a moody student, he hardly focused on the class since he was in the first grade. The writer knows him very well since the writer is the homeroom teacher of him. Although Leon sometimes hard to handle, his attitude towards the English lesson does give positive effect to his score. After receiving his questionnaire result, the writer then conducted an interview with Leon. Leon thought that English lesson is very fun and nice, just sometimes he afraid of making mistakes. He may not be the one who achieves the highest score, but at least he does enjoy learning English.

Researchers in the fields of psychology and education, especially language learning, consider several definitions of attitude which mention different meanings from different contexts and perspectives (Abidin, 2012). It is believed that if the children enjoy and relax during the lesson, the materials given are easier for the students to absorb. Also, in daily practice, the students are learning to enjoy the lesson since the lesson was fun and enjoyable for them. It won't be a burden to the students if they enjoy every activity given by the teacher. English teachers in Indonesia must be aware of this situation, they will need to make their class enjoyable for the students so that the class can be less tense. By making the class relax, the students are expected to be more enjoyable in learning the language so that the result will be satisfying for both the parents and their children. As the writer is aware of that situation, she then tried her best to make the English learning in her class as exciting as she could. In the past 10 months, she has made her English class as relaxing as possible but still stick on the syllabus given. In the end, the writer still wants to know the condition of her class by conducting this mini research. This research is aimed to analyze the students' attitude towards English lesson and its effect on their English achievement.

As you can see in table 3 Clara, Helen and Joline have no negative attitudes towards English. However, they are not the one who gets the highest score in English. Surprisingly, the highest score goes to the one who experienced English lesson anxiety. The writer then took one sample of the students whose score is the highest among the class. Carol got 98 as her average score in her English class which is very good. Carol responds to the questionnaire that she was afraid of making a mistake in English. When the writer asked her about that, she answered that her anxiety in making mistakes made her more careful in doing the tests. This 
statement can explain that somehow, students need the anxiety to make them well prepared for the lesson. When they think the lesson will be difficult if they did not pay attention, those students will perform better since they have many preparations before.

\section{DISCUSSION}

Picture 1: The students' positive attitudes

\begin{tabular}{|c|c|c|c|}
\hline Clara & 8 & - & Positive attitude \\
\hline Helen & 8 & - & Positive attitude \\
\hline Joline & 8 & - & Positive attitude \\
\hline
\end{tabular}

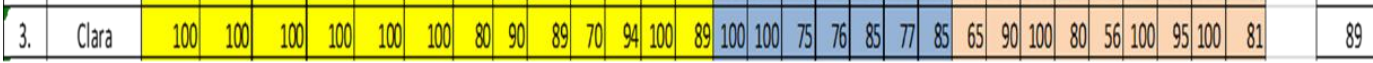

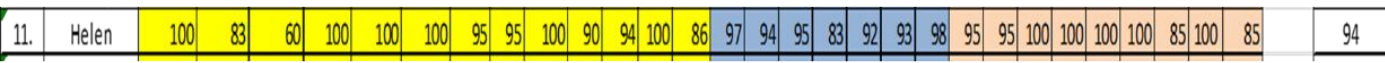

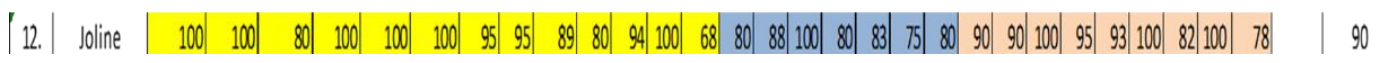

As shown on the picture above, some students did not feel anxious at all when they were learning English. They did not feel that the English lessons they had learned had been difficult or troublesome. Those three students above agreed that English lessons were very enjoyable lessons. When we compared their attitude with their final score, the three students above were not students who get the highest grade in class. Whereas many researchers say that if students feel very comfortable in a situation, they will perform very well. Compare the result in picture 1 and picture 2 below.

Picture 2: The students' anxiety of learning English

\begin{tabular}{|c|c|c|c|}
\hline Name & Positive attitude & Negative attitudes & Result \\
\hline Carol & 6 & 2 & Positive attitude \\
\hline Edgar & 5 & 3 & Positive attitude \\
\hline Devin & 5 & 3 & Positive attitude
\end{tabular}

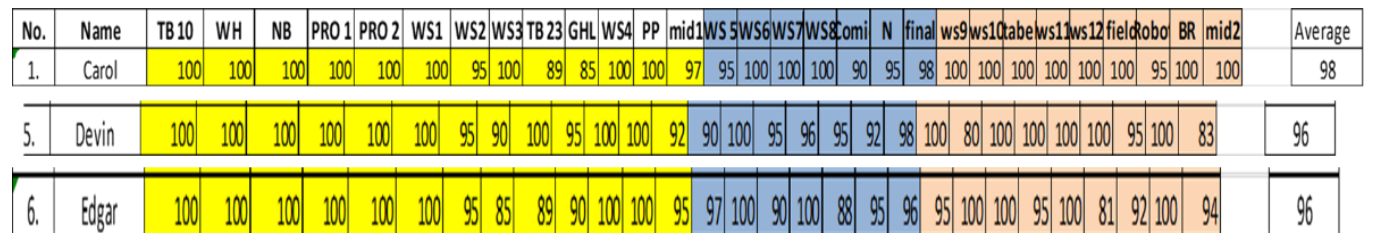

As you can see above, some students who feel anxious in learning English surprisingly got satisfactory grades. Even the three students above, are the top 3 scorers in the class. With this discovery, it can be assumed that anxiety actually does not always bring bad influence or effect to the students. Some of us, need anxiety to produce and perform better.

The effort that the teachers do to make their students enjoy in learning is very important. Imagine if a student with average ability has to learn in a hectic environment. Those students might result in worse English achievement. Teachers and learning environment are the important factors to boost the students' willingness to learn in a class. If teachers can wrap the lesson and make the 
students learn without they even notice, their students' attitudes toward English will be better. The result of this study might be a different one and another depends on the subjects and also the situation. The writer hopes that her study will somehow give vision to the teachers on how to make their lesson likable by the students. Once the students find the lesson is good for them, they will more likely to result in a better score.

As stated by Karahan (2007, p.84) "positive language attitudes let learner have a positive orientation towards learning English". If students have a positive attitude in learning English, the result will be positive as well. From this mini research, the writer can conclude that students' attitudes towards the lesson can somehow give effect to the students' achievement.

\section{CONCLUSION}

After summarizing of the data above, the writer then reflected her English class for the last 10 months. In delivering the lesson, the writer did not lead the class in a tense condition compared to the other English classes. Students are free to talk their mind to the writer. At the very first of the class, the writer has made an agreement with the whole class. The class will be started by discussing the books and materials according to the syllabus given by the Cambridge curriculum. After that, the writer always provides the class with refreshments that the students can choose. The writer usually conducted individual projects, group projects, movie review and even games at the end of the session. The students are the ones who always decide which activity they want to for the whole week. The writer always let the students deliver their opinion about something discussed. When the students disagree with something mentioned in the book, the writer then opens a class discussion to talk about it. From this activity, the writer let her students speak their mind even though, some of her students mixed the language in explaining the topic discussed. In many ways, the writer always tries to give her students as many inputs as she can. She always asks the students to explore the book and sometimes discussing current movies that the students might have watched.

The results of this research might be different from others depending on the subjects and measurements. The findings in this research can be used to reflect how the teachers have to teach in the classroom knowing the fact that somehow some of their students are burdening because their parents to get an outstanding score in a subject they might hate before.

\section{REFERENCES}

Abidin, M. J. Z., Pour-Mohammadi, M., \& Alzwari, H. (2012). EFL students' attitudes towards learning English language: The case of Libyan secondary school students. Asian social science, 8(2), 119.

Granena, G. (2018, December). A critical period to learn a second language? https://www.tradiling.net/a-critical-period-to-learn-a-second-language/

Karahan, F. (2007). Language attitudes of Turkish students towards the English language and its use in Turkish context. Çankaya University Journal of arts and sciences, 1(7), 73-87. 
Moskovsky, C. (2001, September). The critical period hypothesis revisited. In Proceedings of the 2001 conference of the Australian linguistic society (pp. 65-69).

Sukarta, Y. (2017, February). Three common facets of Indonesian international schools.https://www.thejakartapost.com/youth/2017/02/28/three-commonfacets-of-indonesian-international-schools.html 